The construction cost of the power station will be $£ 91$ million; taking into account the initial fuel charges and the interest charges during construction, total costs will be $£ 125$ million, according to the Ministry of Power. A coal fired station of the same size would have cost $£ 76$ million, or $£ 89$ million if interest charges during construction had been included. (On the face of it this seems a very high figure for a coal fired station, but the National Coal Board has not queried the arithmetic, so it is probably right.) The generating cost for the AGR will be 0.52 pence per $\mathrm{KWh}$, while that for a coal fired station would have been 0.70 pence. Of the nuclear generating cost, $0 \cdot 36$ pence is accounted for by capital charges, while in the case of coal only 0.23 pence would have been accounted for in this way. Operating costs for the coal station would therefore have been nearly four times as great, at $0 \cdot 47$ pence against $0 \cdot 16$ pence.

Lord Robens, chairman of the National Coal Board, who has put up a determined fight to make the station coal fired, accepted the decision stoically. There was no point, he concluded, in pursuing guerilla warfare. Even the name Seaton Carew is likely soon to be forgotten, for the CEGB has started to call the station Hartlepool-not, it seems, in the hope of pulling the wool over the eyes of the Durham miners, but simply because there has been a change in the boundaries of the local authority area in which the station will be situated.

It seems likely that the contract for the station will be of the conventional turnkey type. This means that one of the existing consortia will be responsible for building everything in the station from fuel elements to door knobs. By deciding that the station will be an AGR, however, the CEGB may be missing an opportunity of taking advantage of the high temperature technology developed in the Dragon reactor at Winfrith. It also implicitly assumes that an American boiling water reactor built under licence could not compete with the AGR. (A recent study by the Bechtel Corporation in the United States makes this assumption look less shaky than it has in the past. The Bechtel study suggests that the AGR could be competitive in the United States; it is also probably fair to say that the pressure vessel problems, still not entirely solved in the US, favour the AGR.)

\section{POWER STATIONS Where the Wind Blew}

Whether people like it or not, Ferrybridge C Power station will always be remembered as the place where the cooling towers fell down. That happened in November 1965, while the station was being built. The towers, rebuilt and strengthened, have so far shown no signs of a repeat performance, but the Central Electricity Generating Board has movie cameras pointing at them just in case. When the wind blows, somebody rushes out and mans the cameras in the hope of a film which might rival the famous one of the Tecoma Narrows Bridge falling down.

In spite of the disaster, Ferrybridge $\mathrm{C}$ has turned out to be remarkably cheap. It is also now the biggest power station in operation in Britain, capable of generating 2,000 MW(e) when all four of its turbines are at full stretch. The total construction costs of the station will be very near $£ 80$ million, which is equivalent to $£ 40$ per kilowatt installed. Most probably it will never again be possible to build another thermal station as cheaply and the $2,000 \mathrm{MW}$ stations which are to follow will all cost more, thanks to increases in the costs of construction. So far, the most that Ferrybridge $\mathrm{C}$ has generated at any one moment is 1,296 MW (which is said to be the highest ever achieved by a British power station), but everybody hopes that it will achieve maximum rated power when it is opened next week. Each of the four $500 \mathrm{MW}$ sets has been fully commissioned, but there has not so far been a chance to operate them all at full power at the same time.

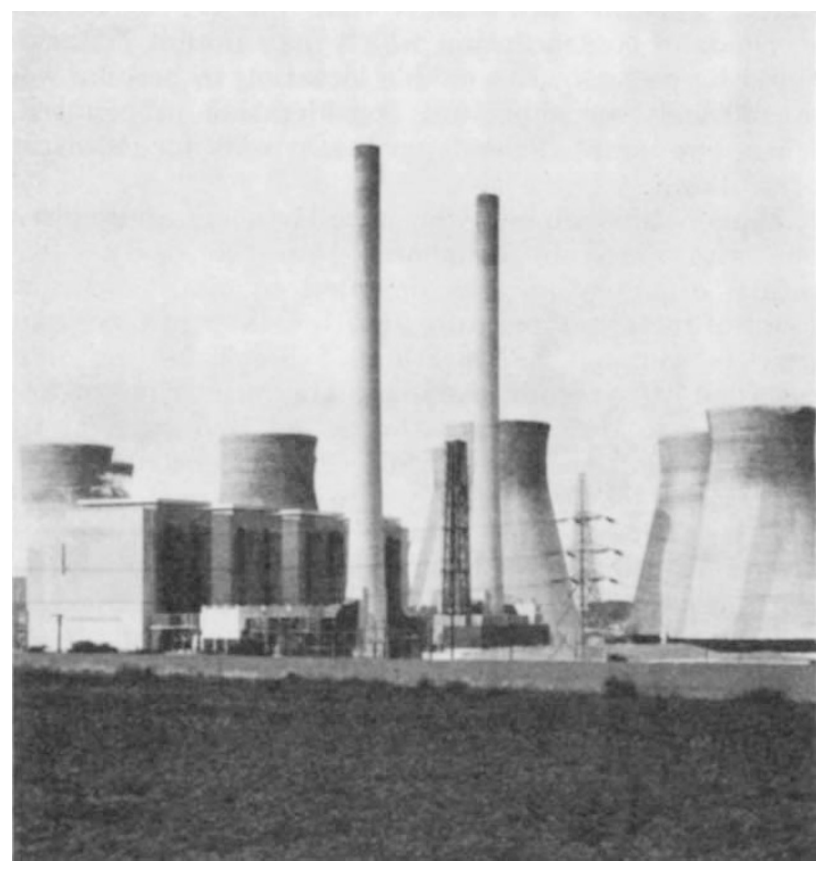

Ferrybridge C power station.

The station is the first to use $500 \mathrm{MW}$ generating sets, made by C. A. Parsons at Newcastle upon Tyne. This was a brave decision, taken before there was any experience with sets greater than $200 \mathrm{MW}$. Mr Leslie Giles, superintendent of the station, points out that $100 \mathrm{MW}$ sets were looked on as monsters only 10 years ago, but courage seems to have been amply justified. A power station this size consumes about 5 per cent of its output simply in operating, so that if the whole electricity network goes completely flat (as in the New York clectricity failure of 1960) it is impossible to start up the station again. To guard against this, Ferrybridge has four Bristol Siddeley aero engines, each capable of generating $17.5 \mathrm{MW}$. Each can be started up in 2 minutes, and can be used either to start the main power station or to supplement its output for very short periods of high demand.

Coal can be brought to the station at the rate of 32,000 tons a day $-8,000$ tons by barge and the rest by rail. The National Coal Board is charging a pithead price of around 4 pence per therm for this coal, which is then used to generate electricity for 0.55 pence per KWh. As the table shows, this generating cost compares well with estimates for later 2,000 MW stations, and with all the nuclear stations before 


\begin{tabular}{|c|c|c|c|c|}
\hline \multicolumn{2}{|c|}{ CONSTRUCTION AND } & \multicolumn{3}{|c|}{ GENERATING COSTS } \\
\hline Station & Size & Cost/KW & Gene & rating costs \\
\hline \multicolumn{5}{|l|}{ Coal : } \\
\hline Ferrybridge C & $2,000 \mathrm{MW}$ & $£ 40$ & 0.55 & pence $/ \mathrm{KWh}$ \\
\hline Rateliffe & $2,000 \mathrm{MW}$ & $£ 41$ & $0 \cdot 54$ & , \\
\hline Cottam & $2,000 \mathrm{MW}$ & $£ 44$ & 0.56 & $"$ \\
\hline \multicolumn{5}{|l|}{ Nuclear } \\
\hline Oldbury & $600 \mathrm{MW}$ & $£ 113$ & 0.74 & \\
\hline Wylfa & $\mathbf{1}, 180 \mathrm{MW}$ & $\mathfrak{E I 0 8}$ & $0 \cdot 70$ & " \\
\hline Dungeness $B$ & $1,200 \mathrm{MW}$ & $£ 81$ & 0.57 & , \\
\hline Hinkley B & $1,250 \mathrm{MW}$ & $£ 71$ & 0.52 & ," \\
\hline
\end{tabular}

Hinkley B. Ratcliffe seems likely to generate at a fraction of a penny less. But it is doubtful that Ferrybridge will be used to supply base load, except perhaps in the first few years of its life. That function is likely to fall to the nuclear stations, with their much smaller fuel costs and less flexible start-up characteristics. For this reason, the staff at Ferrybridge have been conducting tests to see how quickly the station can be started up or shut down. This will be necessary if it is to be used to follow load.

\section{INDUSTRY \\ Unwilling Partner}

Takeover bids these days have to be justified by elaborate arguments-the Industrial Reorganization Corporation sees to that. But last week's bid by the Plessey Company for control of English Electric is even more involved than most. On the one hand, Plessey says that a merger will make rationalization possible in areas where the two companies overlap. On the other, it is equally happy to argue that where there is no overlap the two companies will be complementary, and together would produce a wider range of goods for world markets.

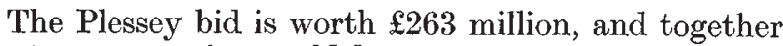
the two companies would form a group even larger than GEC/AEI. While English Electric encompasses products all the way from micro-circuits to large generating sets, Plessey is concentrated at the lighter end of the market. It is a major manufacturer of telephone equipment, and has substantial radar interests bought from Decca. It also has interests in electronic and electrical components, in automation and in "dynamics" - which includes pumps, actuators, valves and the like used in aircraft and industrial control systems. English Electric is a much bigger group; at the heavy end of the market it makes switchgear, transformers and generating sets. It also has a substantial interest in broadcasting equipment, in process control (through Elliott Automation), in aviation radar, and in diesels and dynamics. The principal area of overlap comes in electronics, automation and telecommunications. Only in the third of these can Plessey seriously be considered the senior partner.

Lord Nelson, chairman of English Electric, has said that he cannot understand the industrial logic behind the bid, which implies that he thinks there is none. Although the Industrial Reorganization Corporation has not yet made up its mind, it will have to take a stand eventually, because English Electric owes it $£ 15$ million, borrowed when Elliott Automation was taken over. It would have to give its sanction for the loan to be taken over by Plessey. The other interesting aspect of the bid is that it would give Plessey-never much of a success in computers-a 36 per cent share in International Computers Ltd. This would double its existing shareholding, and the other holders of ICL stock, like Vickers, Ferranti or the Government, might not feel too happy about it. There is also English Electric's 40 per cent interest in the British Aircraft Corporation to be considered. In this sense, a merger between English Electric and Hawker Siddeley would be a much greater contribution to rationalization.

As befits companies in advanced industries, both Plessey and English Electric do their share of research. English Electric, perhaps in the hope of reserving the big guns for its chairman's riposte to the Plessey bid, refuses to say how many people are employed in research or how much is spent. But it runs two laboratories in Stafford, one carrying out research into electrical power supply equipment and the other concerned with the engineering problems of electricity generation and supply. There is a mechanical engineering laboratory in Whetstone, Leicestershire, where there is also a central metallurgical laboratory. The Marconi company has a research division in Essex, concerned with electronics research. Elliott Automation runs eight laboratories, although some of these may have been taken over by ICI.

Plessey is a little more forthcoming about its research activities. Of its 68,000 employees, 7,000 are said to be employed on research and development and the total research offort costs "over $£ 20$ million a year". The central research department, the Allen Clark Research Centre, is at Towcester in Northamptonshire, and is a materials laboratory. The Electronics Group has a research laboratory at Romsey in Hampshire, and another at Havant. There is an environmental test laboratory at Fareham in Hampshire, and telecommunications research is done at Maidenhead in Berkshire. Apart from the Caswell Laboratory, Plessey says that all its research is applied.

Clearly there is considerable scope for rationalization of research; in fact, as in some other British companies, there may be a case for rationalization whether or not the deal goes through. But if it does, research expenditure is likely to be one of the first targets and, if the AEI/GEC pattern is anything to go by, a number of the scientific staff are likely to find themselves out of work.

\section{CLIMATE London's Weuther}

Mr J. H. Brazell of the Meteorological Office has com. piled a book of weather statistics for the London area which promises to become a well-thumbed reference (London Weather, HMSO, 55s.). The objective is to bring up to date the previous classic A Century of London Weather by W. A. L. Marshall, which was published in 1952 and which described London's weather from 1841 to 1949 . The year 1841 is a watershed in the statistics because it is the first year for which regular official meteorological observations are available-observations in the London area started in November 1840 at the Royal Observatory, Greenwich. 